\title{
Environmental Assessment and Analysis of Chemical Properties of Drinking Water Using Geo-Spatial Technologies: Examples from Lahore Metropolitan
}

\author{
Ali Imam Mirza ${ }^{*}$, Ali Iqtadar Mirza1, Tabasam Jamal' ${ }^{2}$, Syed Shehzad Hassan², \\ Muhammad A. Butt ${ }^{2}$, Atif Ali², Hafsa Batool' ${ }^{2}$, Rashid Mahmood ${ }^{2}$, Attia Naz ${ }^{2}$, \\ Azam Sohail'2, Imran Saddique Kaukab'2, Sana Alvi'2, Javed Ahmad', \\ Safeer Ali², Muneeb Aamir ${ }^{2}$, Azeem Akhtar², Arshad Javed ${ }^{2}$ \\ ${ }^{1}$ Department of Geography, GC University, Lahore, Pakistan \\ ${ }^{2}$ Remote Sensing Group, Department of Space Science, University of the Punjab, Lahore, Pakistan \\ Email: *smhn72@gmail.com
}

How to cite this paper: Mirza, A.I., Mirza, A.I., Jamal, T., Hassan, S.S., Butt, M.A., Ali, A., Batool, H., Mahmood, R., Naz, A., Sohail, A., Kaukab, I.S., Alvi, S., Ahmad, J., Ali, S., Aamir, M., Akhtar, A. and Javed, A. (2018) Environmental Assessment and Analysis of Chemical Properties of Drinking Water Using Geo-Spatial Technologies: Examples from Lahore Metropolitan. Advances in Remote Sensing, 7, 259-275. https://doi.org/10.4236/ars.2018.73018

Received: December 20, 2017

Accepted: September 27, 2018

Published: September 30, 2018

Copyright $\odot 2018$ by authors and Scientific Research Publishing Inc. This work is licensed under the Creative Commons Attribution International License (CC BY 4.0).

http://creativecommons.org/licenses/by/4.0/ (c) (i) Open Access

\begin{abstract}
The contamination of drinking water in Pakistan is a serious threat to its citizens. Urbanization leads to an increased demand of drinking water supply that leads to excessive drawdown that further causes lowering of water table. The current WASA (Water and Sanitation Authority) supply network does not fulfill the demand of a growing metropolitan city of Lahore. The drawdown of Lahore is absolutely reliant on Water and Sanitation Authority (WASA) water supply network that causes numerous problems due to inappropriate management of groundwater capital and increased urbanization. This research investigates groundwater qualities: Alkalinity, Arsenic, Calcium, chloride, Total Hardness, Magnesium, Nitrate, $\mathrm{pH}$ and Total Dissolved solids using geographic information system (GIS). Residents of high concentrated towns, like Samnabad Town, Allama Iqbal Town, Gulberg, Data Ganj Bakhsh Town, Ravi Town and Wahga town witness cut-down of water supply mainly due to over burden on tube wells. Chemical properties of drinking water show that most of the parameters were within the allowable limits of WHO whereas the $\mathrm{pH}$, and arsenic values are higher than the average. Arsenic is a carcinogenic element which causes cancer and is higher in the drinking water. Finally, this study identifies highly contaminated groundwater zones and makes it convenient to find actual pollutants. Therefore, plans are needed to protect the aquifer.
\end{abstract}




\section{Keywords}

Water Contamination, Urbanization, Geographic Information System (GIS), Chemical Properties, Carcinogenic Elements, WHO, WebGIS, RS, WASA, DNA, pH, TDS

\section{Introduction}

The decline of the environmental quality has come into being with the start of population increase that intervenes in industrialization, urbanization, modernization and vehicle era. With their introduction in the society, serious threats to air, water, soil, and food brought out and harm animal and plant communities which eventually threaten the human society. The environmental degradation is mainly due to the excessive population growth that leads to high fuel consumption, high rate of waste both in solid and liquid, irresponsible waste disposal, lack of industrial zoning and sustainable infrastructure. Water is a blessing for human beings, animals, plants and marine life. Human consume water in many ways primarily as irrigation to grow crops. It is also used as a source for drinking and cooking purpose and has different uses in industries. Today, water is used as a domestic as well as a commercial product. With the increase in the industrial activities around the periphery urban areas there is a high rate of negative impact over its natural existence. Pakistan has no exception to this, facing serious water degradation, especially in big cities, like Karachi, Lahore, Faisalabad, Rawalpindi, Multan, etc. In Lahore the water quality has affected and threatened the life of its citizens as the degradation of the environment is over its extreme condition. This research addresses the ground water contamination due to the intense misuse of water in urban areas. Pure and healthy quality of water supply is very important because it directly involves the public health. The WHO, (World Health Organization), Europe and United States have standards for water quality. Europe and United States follow their own standards. While countries which do not have their own water quality standards follow WHO water quality standards. In this regard, Pakistan Council of Research in Water Resources is running Water Quality Monitoring Program that ensures the water quality standards of WHO in Pakistan.

Lahore is one of the largest cities of Pakistan having a population of 11,126,285 people according to the 2017 census. The increased residential, commercial and industrial activities, lead to excessive pumping of ground water. Poor, fractured and old pipes, lead to the introduction of sewerage water into fresh drinkable water supply lines. The drinking water has been contaminated and is mixed with other vital substances that impure the drinking water quality. The present study represents the drinking water samples selected for the survey in assessing water pollution in Lahore city. These sample sites are selected on the basis of different land use. This will give the true picture about the existing situation of drinking water in Lahore metropolitan and a proper understanding for the stakeholders 
in future development and for the betterment of the city. Drinking contaminated water is the major cause of early age death and increase in diseases especially in the developing countries. There are two basic sources for drinking water in $\mathrm{Pa}$ kistan, i.e. ground water and surface water. Both are subjected to natural and manmade contamination. There is a very low trend towards the monitoring of water quality and is restricted to only few major cities [1]. The city without control measures is estimated to have a high rate of chemical contamination in the water supplied by the WASA. The rate of arsenic and $\mathrm{pH}$ are higher than the WHO standard. This study will help in identifying the common contamination in the drinking water of Lahore metropolitan and propose the filtration plants for its effective control. The quality of ground water of any region can be affected by man-made activities, land use and pollution sources from different means. There is a need to develop an effective pollution tracking tool that identify the origin of the pollution from the ground water. This will help in improving the efforts made towards water management in a cost-efficient way [2]. The most accepted result of climate change is the increase in the frequency and severity of weather elements. These weather elements create extreme weather events that include heavy rainfall leading to floods, cyclones, droughts, heat waves, extreme temperature range and wildfire. All this can influence the quality of drinking water. It affects the water catchment area as a result of which it contaminates the drinking water [3]. Pakistan is a land which came under the victim of many natural hazards in the past few decades. Moreover, it is fighting against terrorism which brings a state of emergency in the country. The system of distributing urban water holds a critical and important place in retaining public health and population growth. The universality of urban trends, old structures and increasing terrorism risks need proper modeling for giving response to any type of emergency which is unfortunately not very much developed. When giving response to any emergency situation there should be parallel activities that rely on the processing of continues information as well as formulating targeted response actions [4].

Internationally, we may see many countries become the victim in past when they don't address the risk. In 2013, 50,000 inhabitants of a town close to Bonn in North Rhine-Westphalia, Germany were at risk. The situation was taken under notice when frequent complaints from the residents were made regarding the contamination in the drinking water of that town. There was hardly any system for cutting down the water supply and was made after several hours. Residents who came in contact with the contaminated water had a toxic reaction. This was when a highly alkaline solution got mixed with the water supply and increased the $\mathrm{pH}$ value by 12 . The lack of networking and automatic cut-off mechanisms with proper management is needed in such type of emergency conditions [5]. Arsenic is present in air, water as well as in the soil. Drinking water containing arsenic component can cause a wide range of skin and organ cancer. The huge amount of water intake containing arsenic compounds is causing great health issues throughout the world. Excessive concentration of arsenic in the body can damage human DNA [6]. Habitants that did not use piped water as a 
source of drinking has high arsenic concentrations in their body. Communities that are consuming Municipal treated water have a low rate of arsenic concentration in their body. Clinical reports showed that people suffer from weakness and muscular pain, anaemia, and gastrointestinal problems [7].

The amount of arsenic can be increased in cultivable soil once the soil is being irrigated with the arsenic water. This will cause a negative impact on the crops and vegetables [8]. Habitants that use those vegetables and crops grown from the irrigation of arsenic contaminated water have higher concentration of arsenic biologically. Higher consumption of such food leads to high degree of biological changes in the body [9]. A research carried out by [10] about the concentration of arsenic in human hairs. The results show that a high level of arsenic content is found in the hair sample of a newly born baby. Furthermore, the results showed that the arsenic can enter indirectly into the body without and direct excess through food or water intake. Sometimes air particles also become the cause of entering arsenic component into the human body.

Wild fire also threatens the water quality as it transfers eroded ash and soil fragments into rivers and other water reservoirs. The ability to minimize this factor of risk is to formulate effective plans for fire preparedness and to regulate measures after the fire came under control. In October 2013, the Balmoral fire affected 12,694 ha (Hectare) of Sydney's forested water supply catchment. It produces enough ash that had increased with fire intensity, with 6,16 and $34 \mathrm{Mg}$ $\mathrm{ha}^{-1}$ found in areas that are affected by low, high and extreme fire respectively [11]. Alleppey is a densely populated region of the Kerala state south India having a population of about 240,991. The main source of drinking water is groundwater which is mainly distributed through dug and tube wells. The region has excessive fluoride and salinity components in the groundwater due to the excessive pumping from a multi-layer aquifer system which are mainly sedimentary deposits. The water testing shows $62 \%$ of the groundwater of the area belongs to poor quality and is not according to the standards of BIS and WHO. There is a need for a proper system of quality check and treatment of the contaminated water as it is a serious threat to the consumers [12].

The increase in population growth has reduced the per capita water availability from 5000 cubic meters to 1000 cubic meter science 1951 . The boundary of Lahore city has expended double from the last 15 years. Today it covers an area of $1772 \mathrm{~km}^{2}$ and has an estimated population of 11.12 million according to census 2017. Similarly, the change in land use changes the natural water recharge. As more and more concrete structures and carpeted roads are constructed, less open spaces are available for the seepage of rain water for groundwater recharge. Today the groundwater is getting poorer in quality as well as in quantity. This is mainly due to the above-mentioned reason and dryness of river Ravi. The water table decreases at an alarming rate of 0.45 to 1.50 meters annually. The highest decrease in watertable is 46 meters in 2014. The annual pumping is about 1161 MCM whereas the current recharge rate is about 1013 MCM including the recharge from the boundary areas of Lahore. This rate is about $15 \%$ less than the 
pumping of groundwater [13]. The World Commission on Environment and Development (1987), defined sustainable development as "development that meets the needs of the present without compromising the ability of future generations to meet their own needs". This means that we must use water in such ways that will be easy to sustain for coming generations [14]. It has been observed that ground water plays an important part in the development of a region. Water resource especially the ground-water has the potential of controlling the economic development in the inland river basins of arid western China. This is mainly because of its stable quantity and quality. However, the utilization ratio of surface water has been increased in recent times. This has affected the ground-water recharge rate as the runoff has increased and it has declined the ground-water level of the area [15].

\section{Methodology}

The methodology adopted in this research is field surveys that include GPS surveys as well as water samples upon which mapping of chemical parameters were highlighted and concentration of these parameters has been noted. For the collection of water samples sterilized 1.5-liter bottles were used to collect water samples. For the preservation of water, normal fridge temperature was also required. Within 12 hours the samples were sent to the laboratory (Punjab Public Health Department and GC University, Lahore) for testing. The obtained water samples were tested according to their chemical properties. With the help of ArcGIS 9.3 software mapping of these sampling points along with the level of concentration is made that creates a division of high, moderate and low risk zones. The data acquired from water samples estimates the risk zones with the assessment of the intensity of parameters. This risk is being calculated by the weight of these parameters upon which vector data was made using IDW interpolation. Data presentation techniques include digital mapping, statistical techniques, and data classification. Finally, in the end water analysis was shown in the form of risk zones.

\section{Data Source}

Data is being collected from both initial (primary) and secondary sources for conducting this research. Different Government department has participated in this research in sharing their data that is used as a secondary source of information in this research. Primary data includes the collection of water samples from the study area. For this purpose, field survey was conducted and maximum information was collected. This field survey has been conducted in the residential, commercial as well as industrial type of land use in and around the Lahore Metropolitan area. The sampling technique used for sample collection is simple random sample.GPS Survey was conducted to access the location of the sampling sites that helped later for pointing their locations on map. The GPS model, Garmin nuvi 205 Navigator is used while survey. 
Secondary sources include administrative shape file of study area obtained from the Urban Development and planning Sector Department. Additional data like journals and statistical reports were downloaded from the World Health Organization, (WHO) and Environmental Protection Agency EPA official websites.

\section{Sampling Techniques}

The sampling technique applied in this research work is simple random sampling method. Based on the defined land use, i.e. residential, commercial and industrial land use in relation to the population density, samples were collected from Gulberg Town and Data Ganj Bakhsh Town as commercial land use, Samnabad Town and Allama Iqbal Town as Residential land use whereas Ravi Town and Wahga Town as Industrial land use. The sample size for this study is 29 .

\section{Sample Testing}

Proper care and precautionary measures were carried out for bringing water samples to the laboratory. A total number of 09 parameters that include chemical in nature were tested at the laboratory (Table 1).

\section{Results and Discussions}

Today the whole world is facing a common challenge of urbanization and so does the Pakistan. Lahore is a rapid growing city after Karachi in Pakistan and is facing serious problems due to rapid population growth. Due to advance facilities in Lahore city as compared to other neighboring cities there is an additional increase in its population as more and more migrants are promoting the trend of migration in the city. With this shift, clean drinking water is becoming a rare commodity. Clean water supply is considered to be as one most important and essential urban facilities when talking about basic necessities in any urban development. In this regard, the impurities that are found through the testing of drinkable water supplied to Lahore metropolitan is discussed in this chapter.

Table 1. Analysis techniques used for testing water parameters.

\begin{tabular}{ccc}
\hline Sr. No & Parameters & Analysis Techniques \\
\hline 1 & Alkalinity & Titration method \\
2 & Arsenic (ppb) & Test kit method/Atomic absorption spectrometer \\
3 & Calcium & Titration method \\
4 & Chloride & Titration method \\
5 & Total hardness & Titration method \\
6 & Magnesium & Titration method \\
7 & Nitrate & Cd. Reduction by spectrometer \\
8 & pH & pH Meter \\
9 & T.D.S & T.D.S Meter \\
\hline
\end{tabular}


The conducted research analyzes the sample data obtained from 29 drinking water sources. The criteria for this sample selection is based upon three (3) different land uses, i.e. Commercial, residential and industrial land use. In addition, maximum concentration of population is also taken under consideration. For this, six (6) densely populated towns in and around Lahore Metropolitan are selected. These towns are Gulberg and Data Gunj Bukhsh Town as commercial land use, Samanabad Town and Allama Iqbal Town as residential land use, and Ravi town and Wahga Town as industrial type of land use. This chapter describes the quality of portable drinking water as well as its impacts over human life.

\subsection{Alkalinity}

Alkalinity is usually not a big determinant for estimating quality of drinking water. However, the concentration found in the study area has an average rate of $149.89 \mathrm{mg} / \mathrm{L}$. According to the test results, the alkalinity concentration lies within the permissible limits. The highest concentration is $301 \mathrm{mg} / \mathrm{L}$ found at tube well no 25 located at R-block (New) Model Town, Gulberg Town whereas the lowest is $56 \mathrm{mg} / \mathrm{L}$ found at tube well 21 located at Usman block Garden Town, Samanabad Town. Figure 1 shows its spatial distribution.

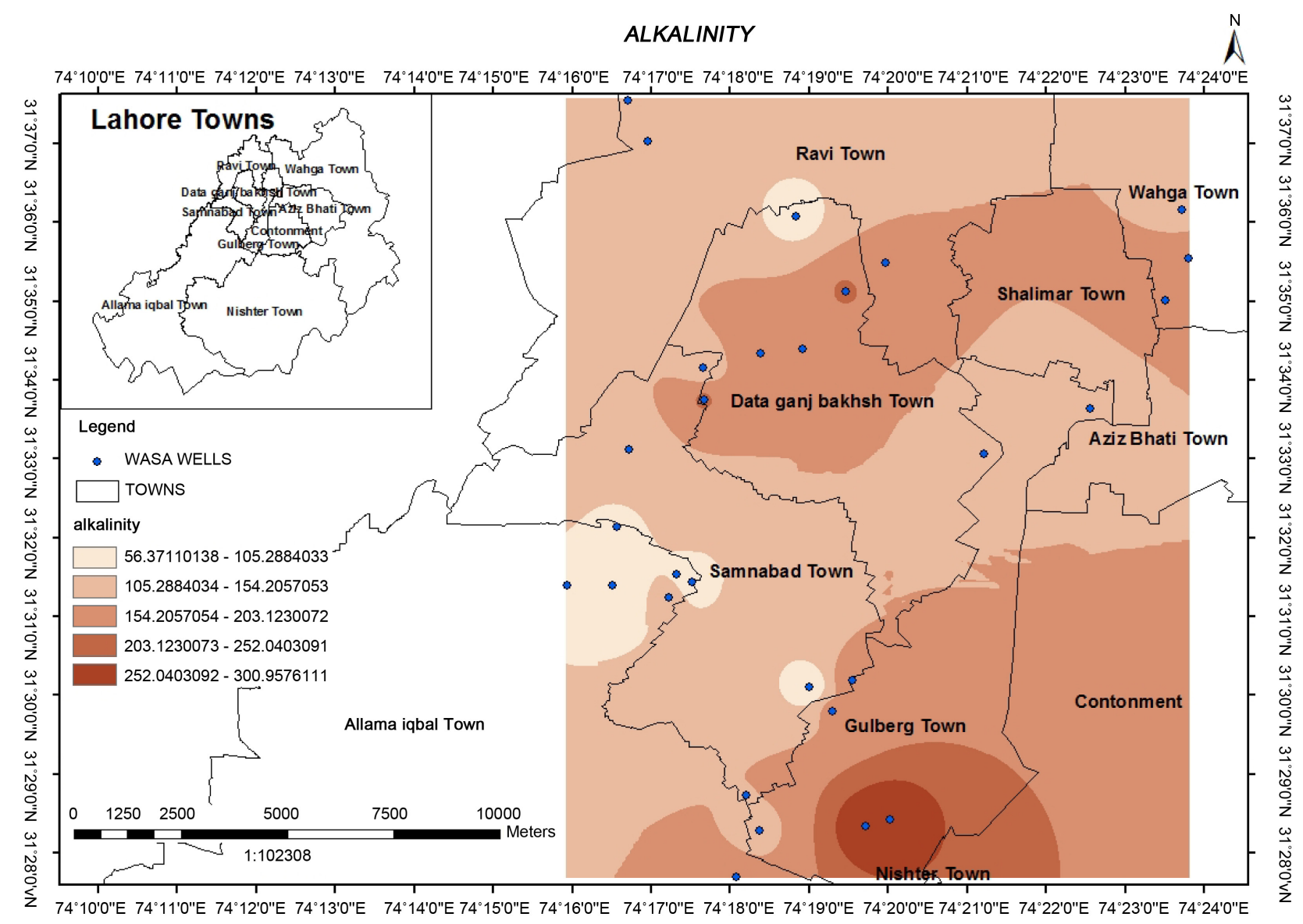

Figure 1. Spatial distribution of alkalinity in the study area. 


\subsection{Calcium}

The concentration for Calcium found in the study area has an average rate of $38.34 \mathrm{mg} / \mathrm{L}$. According to the test results, the Calcium concentration lies within the permissible limits. The highest concentration is $131 \mathrm{mg} / \mathrm{L}$ found at Tube well 6 which is located at Sheranwala Gate, Data Gunj Bakhsh Town whereas the lowest is $13 \mathrm{mg} / \mathrm{L}$ found in tube well 27 located at Block 6, Sec A2 Town Ship, Allama Iqbal Town. Figure 2 shows its spatial distribution.

\subsection{Chloride}

The most common method used to purify water is chlorination. The maximum limit for chloride concentration in drinking water is $600 \mathrm{mg} / \mathrm{L}$. However, if the proportion of chloride exceeds the permissible limit then the water is unfit for human use. The concentration for chloride found in the study area has an average rate of $33.13 \mathrm{mg} / \mathrm{L}$. According to the test results, the chloride concentration lies within the permissible limits. The highest concentration is $65 \mathrm{mg} / \mathrm{L}$ found at tube well 5 located at Nasir Bagh, Data Gunj Bakhsh Town whereas the lowest is $17 \mathrm{mg} / \mathrm{L}$ found at tube well 23 and 29 located at B-block Faisal Town Gulberg Town and Nepier Road Mayo Hospital, Data Gunj Bakhsh Town. Figure 3

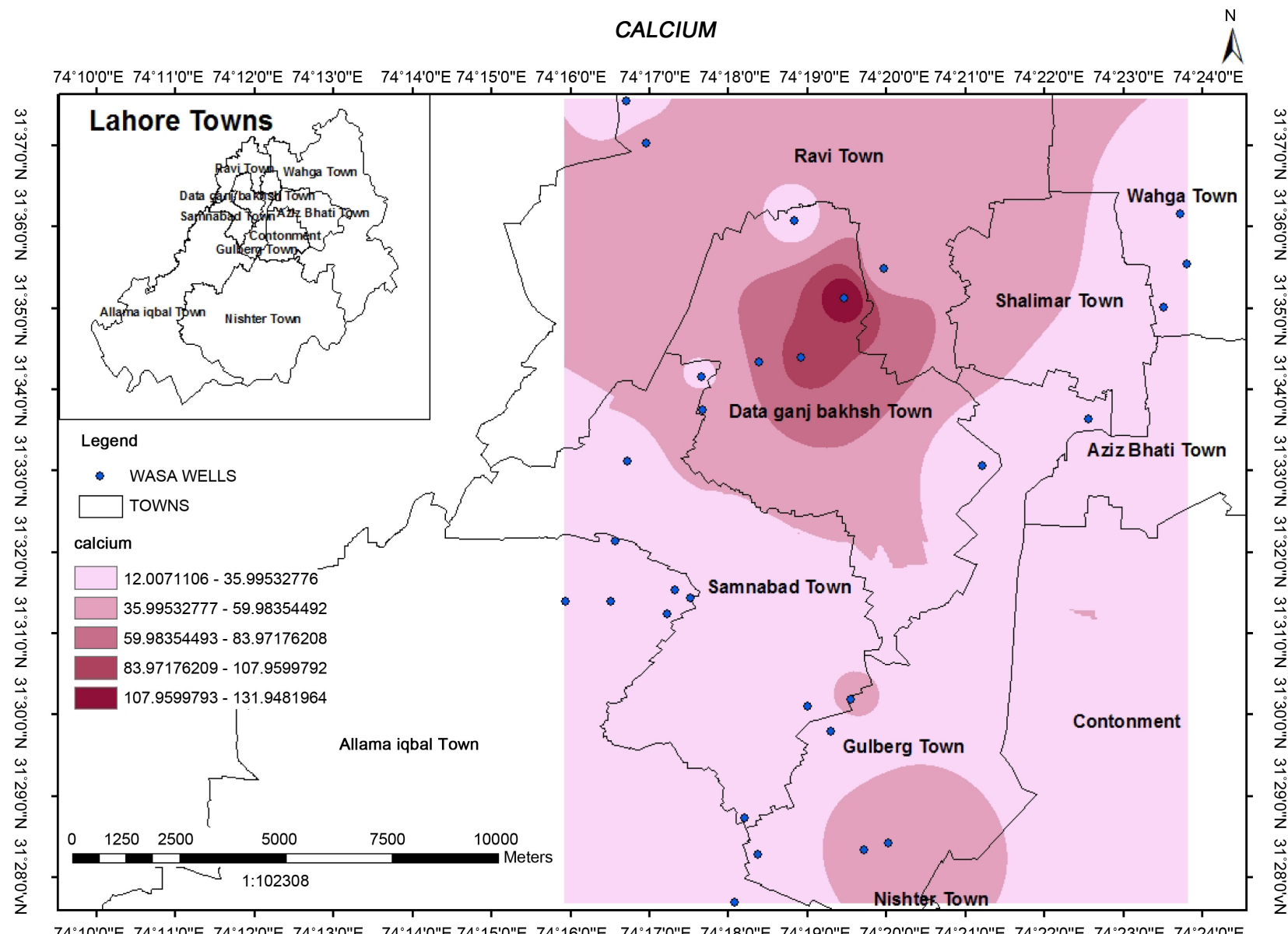

Figure 2. Distribution of calcium in the study area. 


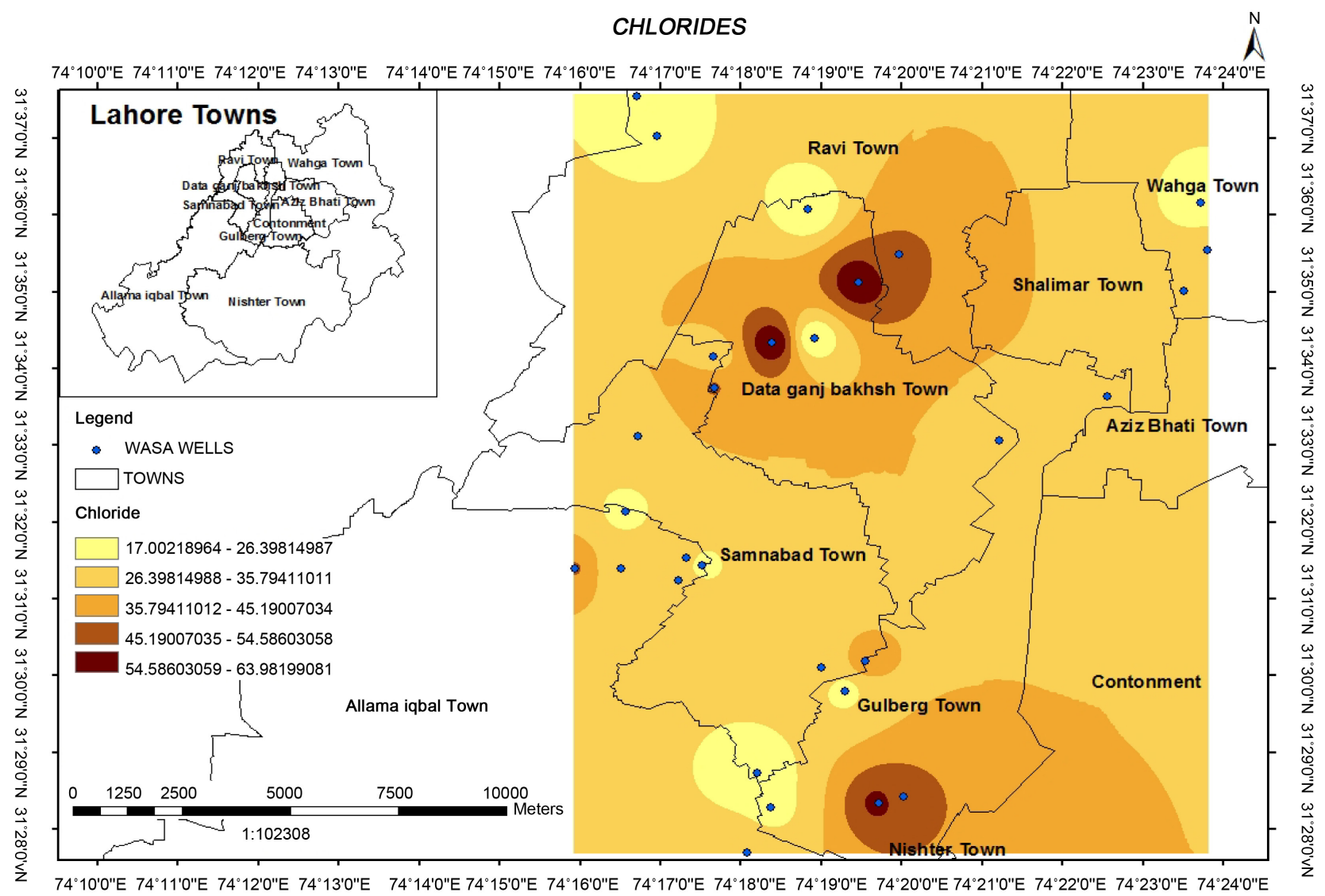

Figure 3. Spatial distribution of chloride in the study area.

shows its spatial distribution.

\subsection{Hardness}

WHO standard explains that the hardness level of drinkable water must not exceeds by $500 \mathrm{mg} / \mathrm{L}$. The highest hardness level is $491 \mathrm{mg} / \mathrm{L}$ found at tube well 29 located at Nepier Road Mayo Hospital, Data Gunj Bakhsh Town whereas the lowest level is $59 \mathrm{mg} / \mathrm{L}$ at tube well 28 located at Zaman ParkGunj Bakhsh Town. The Figure 4 shows the spatial distribution of hardness in the study area.

\subsection{Magnesium}

WHO standard explains that the level of Magnesium in the drinkable water must not exceeds to $150 \mathrm{mg} / \mathrm{L}$. The concentration for magnesium found in the study area has an average rate of $17.72 \mathrm{mg} / \mathrm{L}$. According to the test results, the magnesium concentration lies within the permissible limits. The highest concentration is $81 \mathrm{mg} / \mathrm{L}$ found at tube well 2 located at Nehru Park, Samanabad Town whereas the lowest is $1 \mathrm{mg} / \mathrm{L}$ found at tube well 3 Babu Sabu Bund Road, Allama Iqbal Town. Figure 5 shows its spatial distribution.

\section{6. $\mathrm{pH}$}

$\mathrm{pH}$ shows the acidic or basic nature of the water. WHO safe drinkable water 


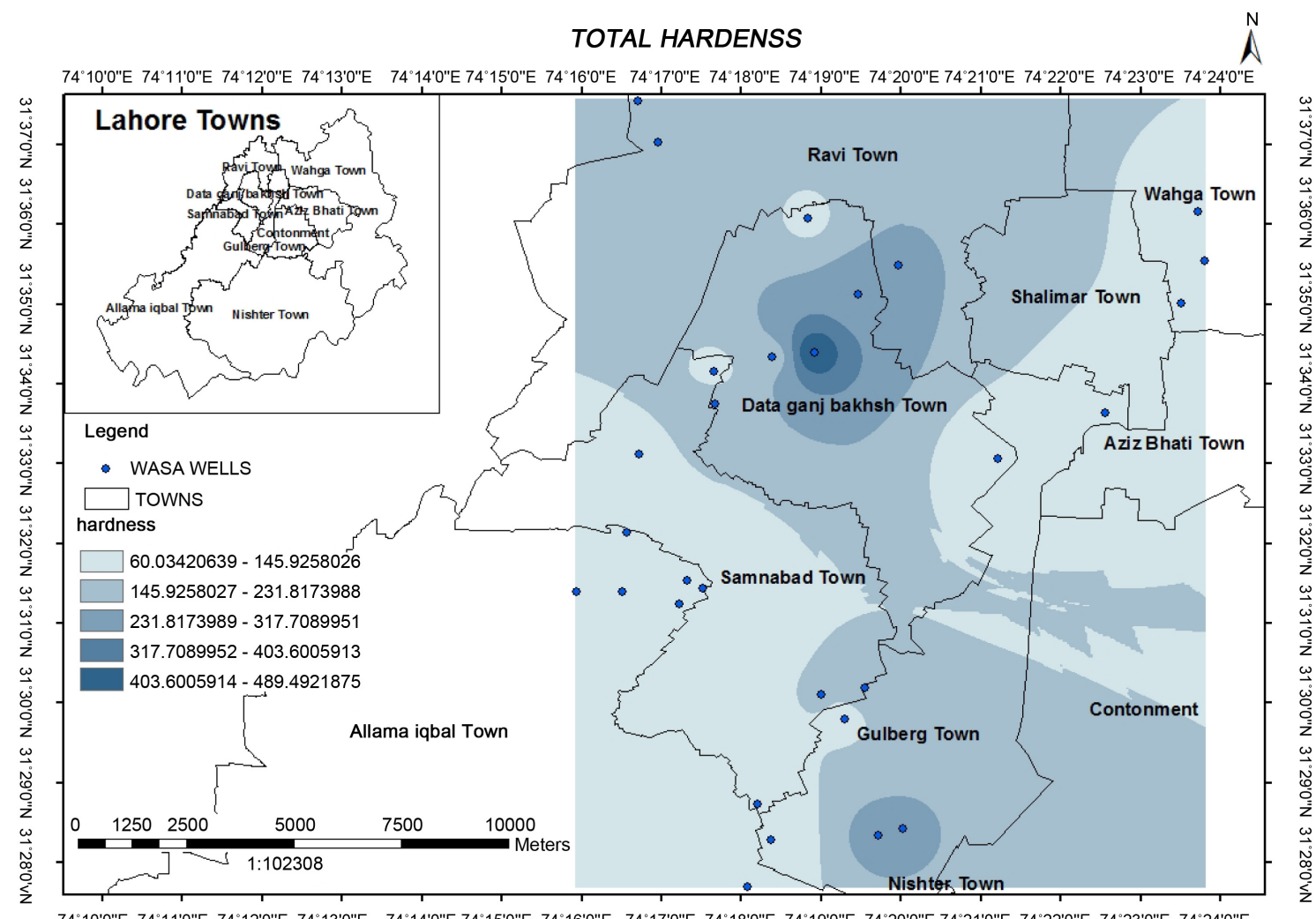

Figure 4. Spatial distribution of hardness in the study area.

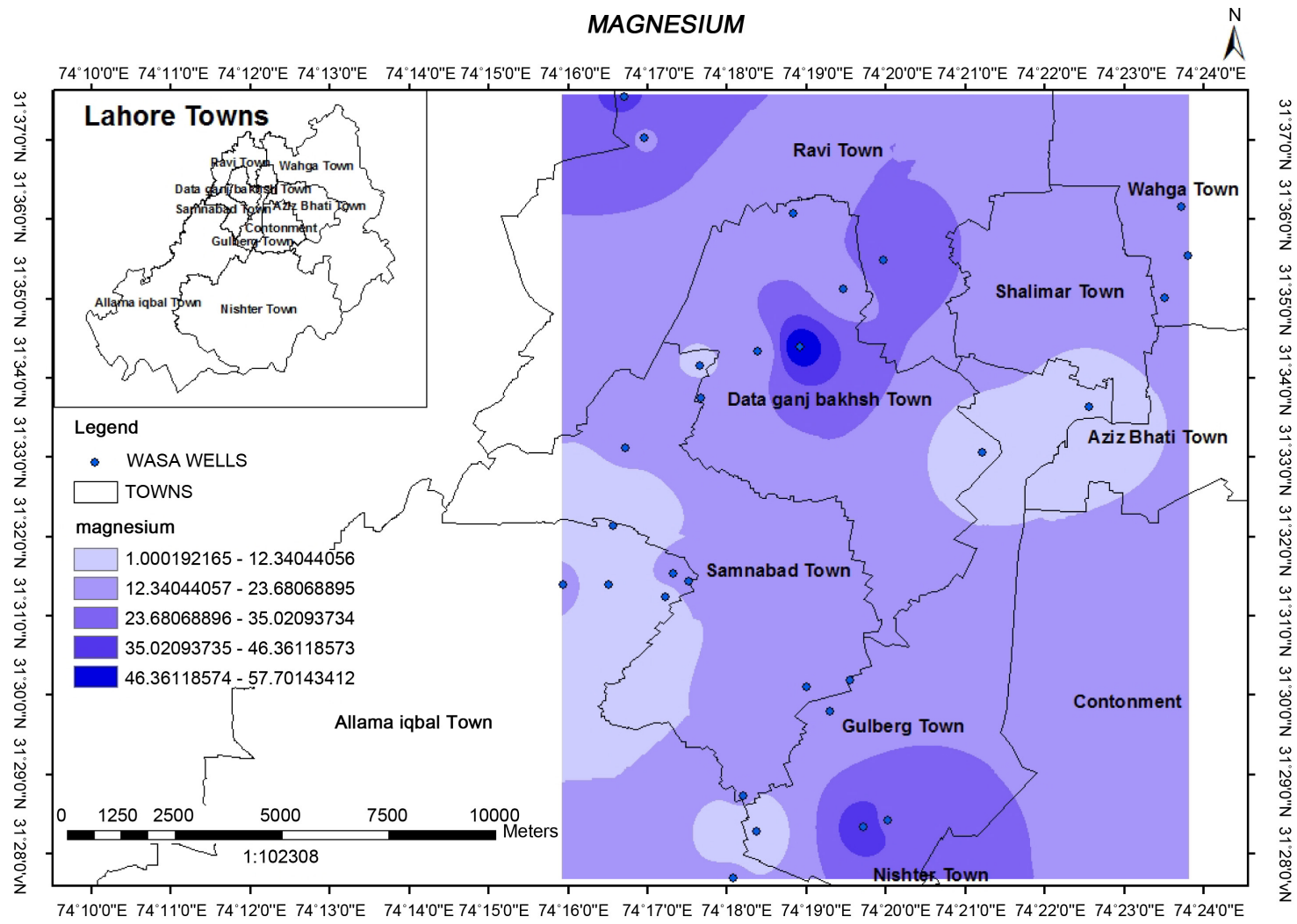

Figure 5. Spatial distribution of magnesium in the study area. 
standard says that $\mathrm{pH}$ must be within the range of 6.5 - 9.2. The observed $\mathrm{pH}$ values have a higher trend value but are within the standard limit. The concentration found in the study area has an average rate of $7.55 \mathrm{pH}$. The highest concentration is $8.24 \mathrm{pH}$ found at tube well 28 located at Zaman Park, Data Gunj Bakhsh Town whereas the lowest is $7.11 \mathrm{pH}$ found at tube well 9 located at Jia Musa, Ravi Town. Figure 6 shows its spatial distribution.

\subsection{Total Dissolved Solids}

Total dissolved solids in drinkable water should not exceed the acceptable limit of $1500 \mathrm{mg} / \mathrm{L}$ as by the standard of WHO. The highest concentration is 1050 $\mathrm{mg} / \mathrm{L}$ found at tube well 29 located at Nepier Road Mayo Hospital, data Gunj Baksh Tuwn whereas the lowest is $191 \mathrm{mg} / \mathrm{L}$ found at tube well 7 located at Sadiq Pura, Data Gunj Bakhsh Town. Figure 7 shows its spatial distribution.

\subsection{Nitrates}

According to W.H.O the permissible limits for nitrate in the drinkable water 45 $\mathrm{mg} / \mathrm{L}$. The highest concentration is $2.92 \mathrm{mg} / \mathrm{L}$ found at tube well 9 located at Jia

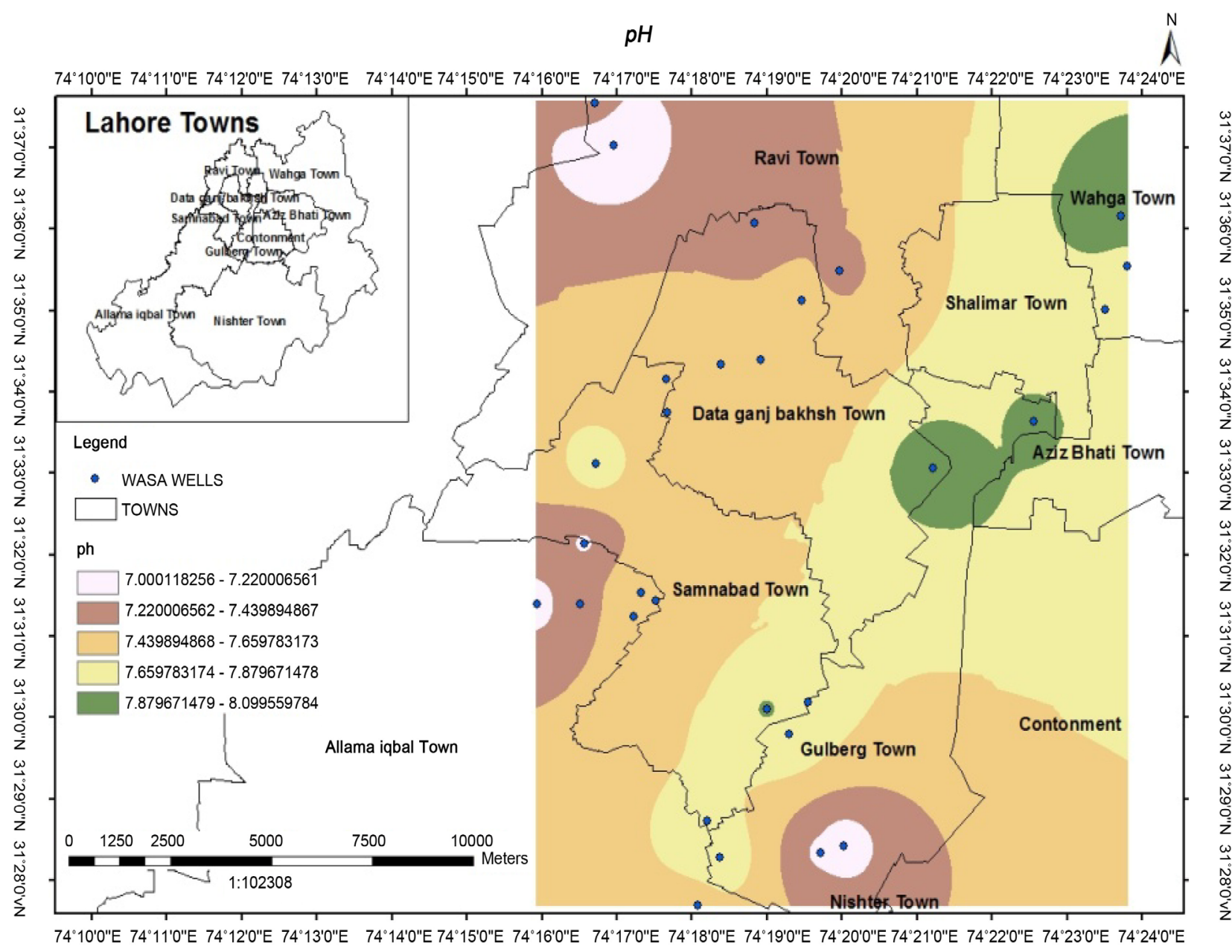

Figure 6. Spatial distribution of ph in the study area. 


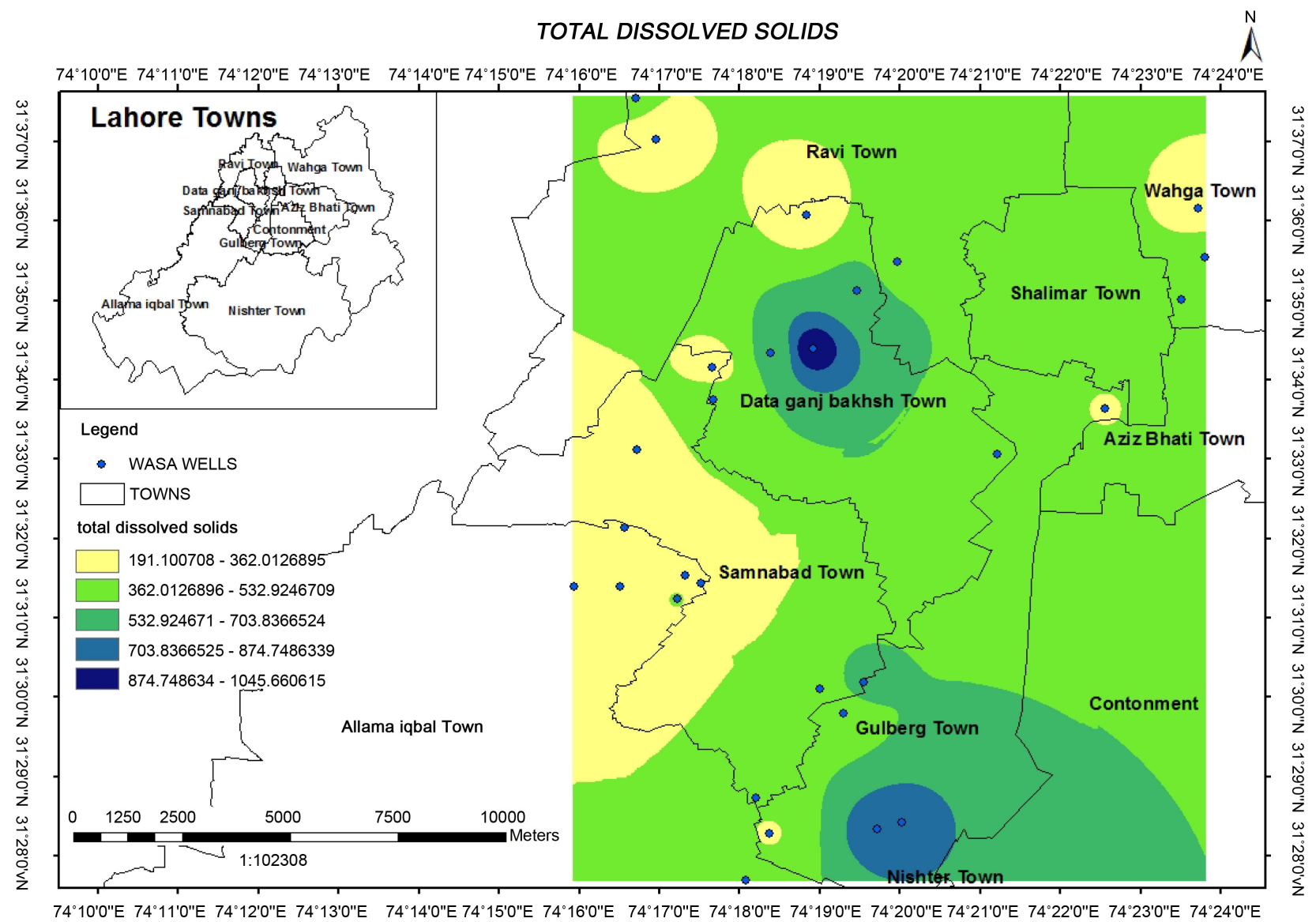

Figure 7. Spatial distribution of total dissolved solids in the study area.

Musa, Ravi Town whereas the lowest is $0.28 \mathrm{mg} / \mathrm{L}$ found at tube well 28 located at Zaman Park, Data Gunj Bakhsh Town. Figure 8 shows its spatial distribution.

\subsection{Arsenic}

Arsenic in drinkable water should not exceed the acceptable limit of $50 \mathrm{ppb}$ as by WHO Standard. The concentration for arsenic found in the study an average rate of $46.89 \mathrm{ppb}$. The highest concentration is $100 \mathrm{ppb}$ found at tube well 9 located at Jia Musa, Ravi Town whereas the lowest is $24 \mathrm{ppb}$ found at tube well 3 located at Babu Sabu Bund Road, Allama Iqbad Town. Figure 9 shows its spatial distribution.

\subsection{Discussion}

Drinking water quality directly revolves around the human health and is being studied in the research in terms to chemical parameters. The obtained samples were compared with WHO water quality standard. If the parameters exceed the acceptable limits of WHO standard, then the water become unfit for the drinking purpose and will eventually cause sickness and diseases. The drinking of heavy water has been widely reported throughout the world. Due to its insoluble state, heavy metals gather in different organs of human body including kidney, 


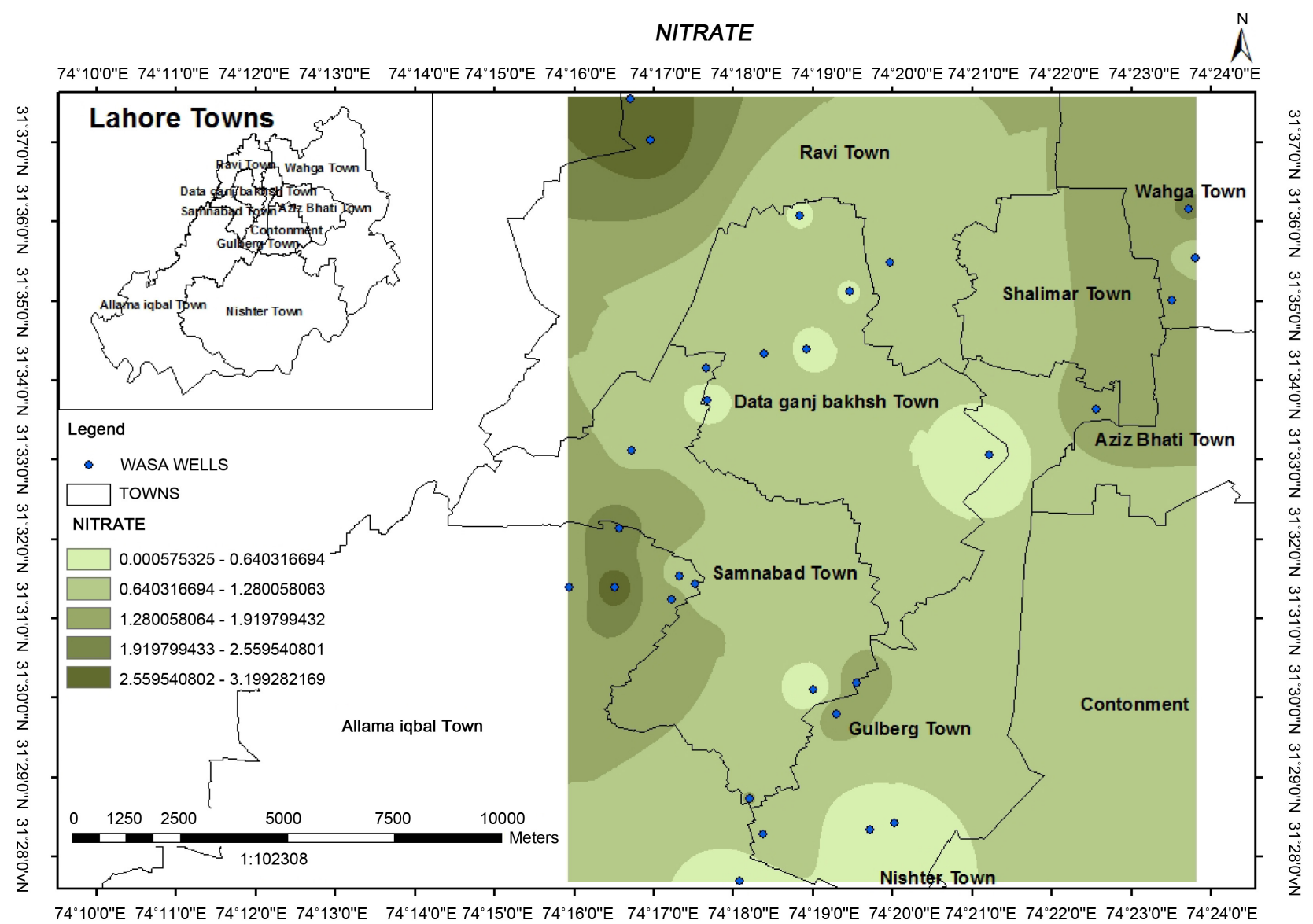

Figure 8. Spatial distribution of nitrate in the study area.

bones and liver which leads to serious health disorder [16].

Most of the parameters have positive relation with other parameters so as if one component increases the other component also increases. This may also have a negative relation with other components as well which when one component decreases the other also decreases.

Lahore is second largest city of Pakistan in terms of population. This study was conducted to access the quality of drinking water at the sources end, i.e. tube wells installed by WASA in the study area. The survey was conducted in areas on the basis of their high concentration in terms of population with a selection of pure residential, commercial and industrial land use. For this 6 town in and around Lahore metropolitan were studied that showed the population concentration as well. These tows are Gulberg Town and Data Ganj Bakhsh Town as commercial land use, Samanabad Town and Allama Iqbal Town as residential land use, and Ravi town and Wahga town as industrial land use. For this 29-sample site has been selected within these towns and samples were collected at the source end of portable water to access the ground water properties. The chemical parameters were tested at the laboratory and were compared with the standard of $\mathrm{WHO}$ as a reference.

Hardness of drinking water is within the acceptable limit of WHO portable 


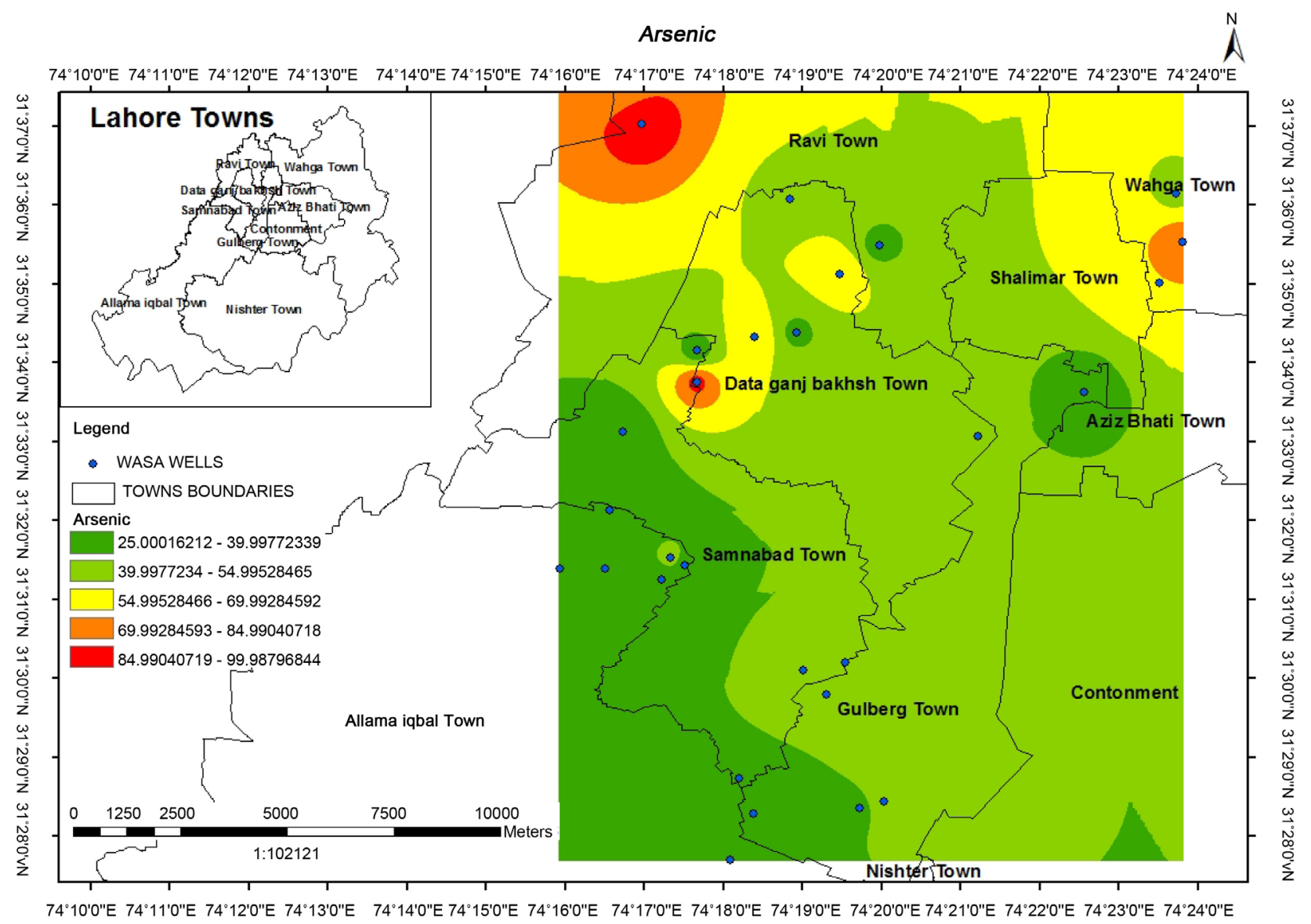

Figure 9. Spatial distribution of arsenic in the study area.

water quality standard. High rate of Hardness in the drinking water is due to the presence calcium and magnesium. The acceptable limit for hardness in the water as far as WHO standard is concerned is $500 \mathrm{mg} / \mathrm{L}$. Above than this proportion the human cannot tolerate. $\mathrm{pH}$ values are also within the acceptable limits however the trend is towards the higher proportion. The average amount of $\mathrm{pH}$ is 7.5. The alkalinity in the drinking water is within the limits.

Arsenic on the other hand is beyond the permissible limit of WHO water quality standard which is very harmful not only because it becomes a reason for cancer but also have a strong impact towards the reproductive process. The areas that have high rate of arsenic proportion in drinking water are Sanda Road Tikoni Ground, Nasir Bagh, Sheranwala Gate, Jia Musa, Chatta Park Azadi Colony, Pakistan Mint, and Dhobi Ghat (Tube well 1, 5, 6, 9, 10, 17 and 18 respectively). Drinking water containing arsenic component can cause a wide range of skin and other organ cancer. The huge amount of water intake containing arsenic compounds is causing great health issues throughout the world. Excessive concentration of arsenic in the body can damage human DNA [17].

The proportion of turbidity in the study area is within the acceptable limits of WHO water quality standard. Calcium, Chloride, Magnesium, Nitrate and TDS's are within the acceptable limits of WHO portable drinking water standard 
in the study area.

The introduction of impurities in the drinking water of Lahore metropolitan is mainly due to the old system of water supply that includes a network of crack pipelines. The cracked pipes installed at tube wells and otherwise might get contaminated as they are exposed to the under laying surface. These cracked pipelines have been running with the sewage pipelines. When the water is pumped from the well these cracks may suck the content of sewage pipes as well.

Another reason of ground water contamination is the flooded condition, i.e. when rain water seeps and gets impurities of the ground such as garbage, waste water, the content of these impurities get mixed with the rain water and seeps into the ground. This will eventually pollute the ground water. Such a case is seen where hug dumps as well as waste water drains are located. Garbage dumps and waste water drain are not properly designed and huge amount of water get seeps with it having their side effects directly on the vegetation, human beings and animals.

Waste water coming from industries, domestic as well as municipal waste has become a serious problem to urban development. Most of the waste water is directly discharge into the water channels that supply irrigation water to the crops. Such a case is seen in the BRB and Mian Mir canal. Less than $50 \%$ of the waste water in an urban city can be collected into a sewage collection system which will eventually become a part of a water channel; whereas only $10 \%$ of the waste water gets treated and discharged into a drain properly [18].

Human activities mostly cause water pollution [19]. The primary reason for this cause is the unsafe disposal of wastewater into the water bodies like, canals, lakes, rivers, etc [20]. According to an estimate about $70 \%$ of the industrial waste and $90 \%$ of the raw sewage get untreated discharge into the water body in the developing world. And this percentage is much higher in the under developing nations. In Pakistan approximately 2000 million gallons of sewage gets untreated discharge into the water channels daily [21]. All these factors become the reason of impure ground water which directly threatening the human lives.

\section{Conclusion}

The contamination of drinking water in Pakistan is a serious threat to its citizens. Urbanization leads to an increased demand of drinking water supply that leads to excessive pumping. The current WASA water supply network does not fulfill the demand of growing city, Lahore. Residents of high concentrated towns, like Samnabad Town, Allama Iqbal Town, Gulberg, Data Ganj Bakhsh Town, Ravi Town and Wahga town witness cut-down of water supply mainly due to over burden on tube wells. Chemical properties of drinking water show that most of the parameters were within the allowable limits of $\mathrm{WHO}$ whereas the $\mathrm{pH}$, and arsenic values are higher than the average. Figure 6 and Figure 9 show the concentration of these parameters in the study area. Arsenic is a carcinogenic element which causes cancer if its concentration is higher in the drinking water. Lahore is pre- 
sently facing numerous drinking water problems, such as water scarcity, localized water contamination, small recharge sites, and over-drawdown of this natural resource. The main sources of contamination in the study area are poorly managed sewerage systems, polluted river water, and mismanaged landfill sites. These issues will develop into worst scenario if immediate steps will not be taken in near future by the policy makers. It is predicted that the current study will provide some guides for the development of a comprehensive land use and water administration plan.

\section{Conflicts of Interest}

The authors declare no conflicts of interest regarding the publication of this paper.

\section{References}

[1] Bhowmik, A.K., et al. (2015) Mapping Human Health Risks from Exposure to Trace Metal Contamination of Drinking Water Sources in Pakistan. Science of the Total Environment, 538, 306-316. https://doi.org/10.1016/j.scitotenv.2015.08.069

[2] Tran, N.H., et al. (2015) Fecal Pollution Source Tracking Toolbox for Identification, Evaluation and Characterization of Fecal Contamination in Receiving Urban Surface Waters and Groundwater. Science of the Total Environment, 538, 38-57. https://doi.org/10.1016/j.scitotenv.2015.07.155

[3] Stuart J.K., et al. (2015) Extreme Weather Events: Should Drinking Water Quality Management Systems Adapt to Changing Risk Profiles? Water Research, 85, 124-136. https://doi.org/10.1016/j.watres.2015.08.018

[4] Rasekh, A. and Brumbelow, K. (2015) A Dynamic Simulation-Optimization Model for Adaptive Management of Urban Water Distribution System Contamination Threats. Applied Soft Computing, arXiv:1407.0424v1. https://doi.org/10.1016/j.asoc.2015.03.021

[5] Lendowski, L., et al. (2015) Accidental Contamination of a German Town's Drinking Water with Sodium Hydroxide. International Journal of Hygiene and Environmental Health, 218, 366-369. https://doi.org/10.1016/j.ijheh.2015.01.006

[6] Basu, A., et al. (2001) Genetic Toxicology of a Paradoxical Human. Mutation Research, 488, 171-194. https://doi.org/10.1016/S1383-5742(01)00056-4

[7] Bibi, M., et al. (2015) Human Exposure to Arsenic in Groundwater from Lahore District, Pakistan. Environmental Toxicology and Pharmacology, 39, 42-52. https://doi.org/10.1016/j.etap.2014.10.020

[8] Howe, A., et al. (2005) Elemental Composition of Jamaican Foods 1: A Survey of Five Food Crop Categories. Environmental Geochemistry and Health, 27, 19-30. https://doi.org/10.1007/s10653-004-5671-7

[9] Michaud, D.S., et al. (2004) Arsenic Concentrations in Prediagnostic Toenails and the Risk of Bladder Cancer in a Cohort Study of Male Smokers. American Journal of Epidemiology, 160, 853-859. https://doi.org/10.1093/aje/kwh295

[10] Wu, B. and Chen, T. (2010) Changes in Hair Arsenic Concentration in a Population Exposed to Heavy Pollution: Follow-Up Investigation in Chenzhou City, Hunan Province, Southern China. Journal of Environmental Sciences, 22, 283-289. https://doi.org/10.1016/S1001-0742(09)60106-6 
[11] Santín, C., et al. (2015) Quantity, Composition and Water Contamination Potential of Ash Produced under Different Wildfire Severities. Environmental Research, 142, 297-308. https://doi.org/10.1016/j.envres.2015.06.041

[12] Raj, D. and Shaji, E. (2016) Fluoride Contamination in Groundwater Resources of Alleppey, Southern India. Geoscience Frontiers, 8, 117-124. https://doi.org/10.1016/j.gsf.2016.01.002

[13] Basharat, M. (2016) Groundwater Environment in Lahore, Pakistan. Groundwater Environment in Asian Cities, 2016, 147-184. https://doi.org/10.1016/B978-0-12-803166-7.00008-8

[14] Sophocleous, M. (2000) From Safe Yield to Sustainable Development of Water Resources-The Kansas Experience. Journal of Hydrology, 235, 27-43. https://doi.org/10.1016/S0022-1694(00)00263-8

[15] Zhu, Y., et al. (2004) A Survey: Obstacles and Strategies for the Development of Ground-Water Resources in Arid Inland River Basins of Western China. Journal of Arid Environments, 59, 351-367. https://doi.org/10.1016/j.jaridenv.2003.12.006

[16] Duruibe, J.O. (2007) Heavy Metal Pollution and Human Biotoxic Effects. International Journal of Physical Sciences, 2, 112-118.

[17] Carpenter, S.C. (1998) Nonpoint Pollution of Surface Waters with Phosphorus and Nitrogen. Ecological Applications, 8, 559-568. https://doi.org/10.1890/1051-0761(1998)008[0559:NPOSWW]2.0.CO;2

[18] WWF (2007) Pakistan's Waters at Risk Water and Health Related Issues in Pakistan and Key Recommendations. A Special Report, WWF, Lahore, 1-33.

[19] Hammer, M.J. (1986) Water and Wastewater Technology. John Wiley Inc., New York.

[20] Kahlown, M.A. and Majeed, A. (2003) Water-Resources Situation in Pakistan: Challenges and Future Strategies. In: Water Resources in the South: Present Scenario and Future Prospects, Commission on Science and Technology for Sustainable Development in the South, Islamabad, 21-39.

[21] WB-SCEA (2006) Pakistan Strategic Country Environmental Assessment. Main Report, Report No. 36946-PK, World Bank, Washington DC, 1-66. 